\title{
Possessive Constructions in the Yakut Language
}

\section{Dariya Chirkoeva}

\author{
Professor of the North-Eastern Federal University n. a. M.K. Ammosov \\ Department of the Yakut Language; dchirkoeva@mail.ru
}

Ivan Alekseev

Doctor of Philology, Professor of the North-Eastern Federal University n. a. M.K. Ammosov Department of the Yakut Language; sakha2009@mail.ru

\section{Doi:10.5901/mjss.2015.v6n6s5p141}

\begin{abstract}
This article investigates the system of possessive affixes in the Yakut language differentiated in persons and subject relations; the target feature is typical of all Turkic languages. Grammatical forms of the category of possessiveness are examined, the main phonetic changes in the use of possessive affixes are described, and its role in a word-form among other formal indicators and modifiers is described. More detailed research is dedicated to the main morphological method formed by the means of special forms, so-called affixes of possessiveness regarded as a form of inflection, as well as a word-formation.
\end{abstract}

Keywords: affixes, category, possessives, Turkic languages.

\section{Introduction}

In the Yakut language the concept of possessiveness is much broader than the concept of belonging. Possessiveness as a grammatical category includes the relationship not only between an agent and a particular object, but also a certain relationship between people and compounds with a naming function denoting categories considered as significant for the speaker based on their experience as argued by Zimmer (1971). The emergence of the category of possessiveness initially is based on the logical content, i.e. component "owner" from a logical point of view is associated with the notion of "man". An owner could basically be represented by a human being - a person, but in a figurative sense, it can be an inanimate object.

It should be noted that the category of possessiveness as a characteristic and peculiar phenomenon attracts the attention of many linguists. As a result, the grammatical category of possessiveness was presented in the studies of all Turkic languages. One group of linguists (Dmitriev, Sevortyan, Kononov, Maisel et al.) focused on semantic affixes of possessiveness and others (Baskakov, Ubryatova, Potseluevsky, Balakan,et al.) - on the syntactic functions of the affixes. The category of possessiveness is regarded in the scope of morphological and syntactic categories in grammar studies.

Thus, the category of possessiveness, typical of all Turkic languages, is closely associated with other morphological categories, due to the following factors:

a) the system of the affixes of possessiveness differing in person and numeral;

b) the semantic differences of words with affixes of possessiveness;

c) the difference in the meaning of the words with the affixes of possessiveness and their role in the sentence.

In Yakut the absence of genitive case and extensive use of possessive forms led to the diversity of the category of possessiveness, both in terms of its morphological expression and the field of its functional application.

Linguistics in one way or another regularly addressed the issue of the category of possessiveness. The category of possessiveness as an object of scientific study was first considered in the early works of grammar (Kazem-Bek 1846, Boehtlingk 1851, Melioransky 1897, Ashmarin 1898, Melioransky 1900, Yastremsky 1900, Catania 1903).

However, special scientific study of the category of possessiveness in Turkic languages was developed later. Numerous studies (Barker C. 1995, Szabolcsi. A. 1994, Danilova N. 1991) and grammar of Turkic languages emerged extensively paying special attention to the category of possession; monographic studies on specific categories of owning in Turkic languages were widely published 


\subsection{Background}

As a rule, affixes of possessiveness are presented in two shapes depending on whether they attach to roots ending in vowels or consonants. After pointing out some Turkologists' points of view on the primacy of the "vowel option" in the affixes of possessiveness, N.K. Dmitriev came to the conclusion "that both options appeared simultaneously and always existed in parallel, as in the Turkic languages vowel and consonant roots emerge, obviously, at the same time and in parallel" (Dmitriev 1956: 25). The author did a review of the affixes of possessiveness in their "consonant" option. Bashkir, Tatar, Kumyk, Yakut and Chuvash schemes, Turkish, Turkmen, Altai paradigms were selected as examples in the target work. According to the author, the Yakut scheme deserved special attention while noting that "the special feature of the Yakut language is that there is no plural distinction between the affix of possessiveness after the consonant roots and after vowel roots" (Dmitriev 1956: 30).

Despite the vast geographical expansion of Turkic languages the category of possessiveness is inherent in all the languages of the group. The grammatical category of possessiveness is typical of all Turkic languages, the affixes are differentiated by indicating persons and subject relations. Although the concept of possessiveness is typical of any language speaker, it is expressed in each language in different ways.

The ways of expressing possessives were identified in the works of the first Turkologists - Kazembek (1846), Boehtlingk (1851), Jastremsky (1900), Katanov (1903) Radlov (1908) and others. These researchers were the first to note grammatical forms of the category of possessiveness.

There are morphological, syntactic, and combined, i.e. syntactic-morphological ways of expressing the category which are described in works on the grammar of Turkic languages. Linguists have different opinions. Some authors indicate only two ways, others state that the category of possessiveness is formed in two to three or even four different ways.

In the vast majority of Turkic languages the main way of expressing the category is a morphological method that is generated by means of special affixes. In addition to the morphological method, the category of possessiveness can be expressed syntactically, by a combination of the possessive form of personal pronouns with the object of possession. In Turkic languages there is also a third way of expressing possessiveness, the so-called morphological and syntactic, i.e., using personal pronouns in the genitive case and affixes of possessiveness agreeing with the possessor attached to the object of possession as in Turkish benim dostum 'my friend'.

In the Yakut language there are two ways of expressing the category of possessiveness, morphological and syntactic mentioned in the works of Boehtlingk (1851), Jastremsky (1900), Radlov (1908) and in subsequent grammars of the Yakut language.

\section{Research Methods}

The comparative, descriptive research methods were used to cover possessive constructions in the group of Turkish languages. Some language features were compared and classified according to their relations, the linguistic relativism stipulating that the structure of the language directly reflects the structure of the universe and of the human mind forming life perception.

\section{Results and Discussion}

The forms of possessiveness in Turkic languages are classified into three groups: 1) affixes of possessiveness in the first person singular and plural; 2) affixes of possessiveness in the second person singular and plural; 3) affixes of possessiveness in the third person singular and plural.

Affixes of possessiveness in Turkic languages have a close connection with the forms of personal pronouns. The development of affixes of possessiveness in personal pronouns can occur with: 1) a simple reduction and sound reduction; 2) case forms of the personal pronoun and, moreover, in most cases a form of the genitive; 3) may be formed from the content form of a word.

As known, the question of the origin of affixes of possessiveness in Turkic languages continues to draw attention of many linguists.

The question of the origin of possessive affixes in the Yakut language is still open. Assuming that the ways of in which $1^{\text {st }}$ and $2^{\text {nd }}$ person affixes are formed in the Yakut language are typologically similar to the formation of these affixes in other Turkic languages, it should be emphasized that they differ significantly from other Turkic affixes of possessiveness in the form of the first person plural: instead of Turkic -byz, -but is used, $2^{\text {nd }}$ person pl., instead of -syz - - 
ryt. In the Yakut language affixes of possessiveness as well as personal pronouns express the concept 'my', 'your', 'his', etc. So, instead of min djiem 'my house', one may also use only djiem, which also means 'my house', and it is the latter form which occurs more frequently both in literature and in everyday speech. The general grammatical meaning of the word form djiem 'my house' is characterized with the possessiveness affix - $m$, in other words, the Yakut affixes have various syntactic functions corresponding to the notional values of personal pronouns, including personal reflexive pronouns.

Thus, the category of possessiveness in Yakut and other Turkic languages finds its direct expression in the affixes of possessiveness. Selection of affixes within each type is determined by the number of words' roots and their vocal composition in accordance with the laws of vowel harmony. Thus, in the singular when affiliating the affix of possessiveness to roots ending in a consonant there should be a connecting vowel inserted in the affix of possessiveness.

When forming a noun with affixes of possessiveness in the Yakut language a series of phonetic changes inherent in other Turkic languages take place:

1. When affixes of possessiveness attach to roots ending in consonants, assimilation phenomena are observed: at + byt>appyt 'our horse' murun+ byt>murummut 'our noses' etc.;

2. When the $3^{\text {rd }}$ person singular affix $-a(-e,-0,-i)$ is added, there occurs a change of the final stem consonant from $-p,-k$, -kh to $-b,-g,-\gamma$ : sap $+a>$ saba 'his cotton' $\mu t \mu l \mu k+e>\mu t \mu l \mu g e$ 'his gloves' kharakh + a>kharara 'his eyes' etc.;

3. When $1^{\text {st }}, 2^{\text {nd }}$ and $3^{\text {rd }}$ persons singular affixes attach to roots ending in $-s$, $-s$ changes into $-h: k y y s+(y)$ $m>$ kyyhym 'my daughter', kyys + (y) $\eta>k y y h y \eta$ 'your daughter etc. ;

4. When possessive affixes attach to some disyllabic root, there occurs a consonant interchange $r / n$. For example, saryn + a>sanna'his shoulder', murun +a>munna'his nose', kharyn + a>khanna'his stomach', orun + o>onno' his place'), etc.;

5. When adding possessive affixes to words khooy 'sinus' and mooy 'neck' there is an alternation y / nny: mooy + (y) m>moonn'um 'my neck' khooy + (y) n>khoonn'un 'your sinus', mooy + o>moonn'o 'his neck', etc.;

6. When deriving a word with the help of possessive affixes as in $s \mu r \mu n+(\mu) m>s \mu n n ' \mu m$ 'my backbone', there is an alternation of $\mathrm{rn} / \mathrm{nny}$ : sirin + e>sinn'e 'its udder, etc.;

7. When adding possessive affixes to some disyllabicstems, narrow vowel omission occurs: balys $+(y) m>b a l t y m$ 'my sister', kœh $\mu s+(\mu)$ m>kœkhs $\mu m$, 'my back' saryn + (y) m>sannum ' my shoulder, etc.

Personal possessive affix in the first person singular in the Yakut language has two phonetic variants: after roots ending in a vowel its form is - $m$, after roots in a consonant its variants are -(u)m, - (i)m, -(u)m, -( $\mu) \mathrm{m}$ : tœbœm 'my head', tabam 'my deer', byharym 'my knife.

The $2^{\text {nd }}$ person singular possessive affix is closely related to the personal pronoun in the nominative of the same person. As known the pronoun en 'you' is not only a special indicator of the addressee in a speech act, but also the expresser (indirectly) of subjectivity of the narrative which is indicative of the speaker, his presence in the speech situation. The pronoun en 'you' appears in the vicinity of the min 'I', somehow presented in the statement or elsewhere in response to the addressee. Also, the pronoun en in the Yakut language expresses the concept of 'your' acting as defined in the sentence: En oskuolara uirenerin ' Do you attend school' or Min uirenebin, ottonenuirenerin duo? 'I do and do you? In these examples pronoun en 'you' is used in the expression of the subject - the speaker and as an indicator of dialogic speech.

The second meaning of the pronoun en as the determiner with the meaning 'your' can be expressed with the $2^{\text {nd }}$ person singular possessive affix - $\eta$, -yn when the pronoun en 'you' is omitted: En oron tuygunnuk $\mu$ irener 'Your child studies very well'. Oron tuygunnuk $\mu$ irener 'Your child studies very well. "-n'affix expresses the concept of en 'yours'. This usage is widespread in speech Uolun sudaaryskay buolan buten kalbit buolbat, duo, emeekhsien! - Sidpit byraatyn kyncharyyan kebiste'- Old woman, your son has arrived, becoming a complete sudar! - Fedot stared at his brother."

The $1^{\text {st }}$ person plural possessive affix in the Yakut language after any root has forms -byt (-bit, -but, -but), for example, uolbut 'our son' byraappyt 'our brother'. Comparing the affix of possessiveness in the $1^{\text {st }}$ person plural with the personal pronoun of the same person and number, you will notice that they are close by value. Both pronouns and affixes of possessiveness include a semantic volume of a component such as plurality. For pronouns, this means a noun of not a single person in his communicative role, but two or more. This multiplicity appears less obvious than in the category of numerals. But in addition to the expression of person, the pronoun bihigi 'we' refers to the concept of possessiveness.

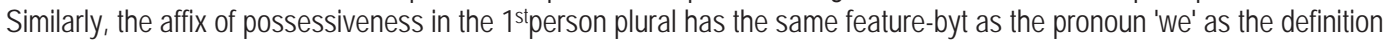
of 'our'. This form has the notion of identity. If in bihigi with the word meaning 'our' passiveness and multiplicity are seen as a set of aggregation expressed with pronoun bihigi, the multiplicity and at the same time possessiveness of the noun 
form arabyt 'Our Father' is in fact a grammatical status as expressed with word-changing affixes -byt (- bit-but, -but). Affix -byt includes meaning bihigi of pronoun 'we', so the concept of possessiveness remains in the pronoun omission: Bihigi tiergemmit yraas 'Our yard is clean' and Tiergemmit yraas 'Our yard is clean'. It once again confirms the assumption of common origin of personal pronouns and affixes of possessiveness.

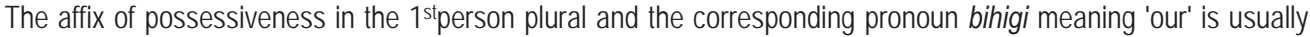
presented as a compound of min 'i' + en 'you' min 'i' + Kini 'he' min 'i' + kiniler 'they' min 'i' + erigi 'you'. For example, in the sentence Agabyt kelle 'Our father came' the affix of possessiveness can express:

1) The combination of min 'my' and en 'your', which means that in this case itrefers to my father and yours. i.e. in the meaning -byt duality of the subject numeralis expressed: "the speaker + another person";

2) The combination of min 'my' and ehigi 'your', i.e. refers to my and at the same time your father; this value is close to the previous sentence due to communication nature, as in this case aggregation is expressed as well with connection of a speech initiator with other persons, namely with a group of partners. In the first case, definiteness and specificity of min 'l'+en 'you' are expressed, this value implies a certain ambiguity min 'i' + ehigi 'you';

3) The combination of min 'my' and Kini 'his', i.e. expresses a particular subject (the speaker) and the object of speech. Affix -byt in this case expresses combination of a speaker and 3rd person, which is presented by a speaker as both the object of speech, and its peer entity;

4) The combination of min 'my' and kini 'their'. This is a case when a speaker unites himself with a particular group of persons. The affix -byt expresses the concept of possessiveness: Uolbut itinten kihirgeete, er ylla byhyylaah 'Our son is getting very proud of it, he has found empowerment in it'. Chugastaagy yallarbyt bihigi kyraky ballgammytygar muhunnular 'Our neighbors have gathered at our house'. Haya, bu "toyommut" de kist $\mu$ but? 'Look, "our lord" appeared finally?'

The $2^{\text {nd }}$ person plural affix of possessiveness has the form -ryt and options (-kyt, -gyt, -hyt, -nyt). The personal pronoun ehigi meaning 'your' and the related $2^{\text {nd }}$ person plural forms are characterized in contrast to the singular pronoun and affix values with more simplicity. For example, in the sentence Arary tkelle 'your father came' or Erigi araryt kelle 'you father came the pronoun ehigi can express: 1) the value of en + en + en ... (+ your +your+ yours ...); 2) the value of en + kiniene (your + his/her); 3 ) the value of en + kiniler (+ your their). In the absence of the pronoun ehigi (your) this value combines affixes of possessiveness: Arary tkelle 'your father came.'

The morphological way of expressing possessiveness combines two types: first, the use of a single noun with an affix of possessiveness; secondly, the use of the noun with the affix of possessiveness and a noun preceding in the nominative case. The first case is usually used in the $1^{\text {stand }} 2^{\text {nd }}$ persons. The expression of morphological features of the first part of possessive constructions in the Yakut language is rendered not only with pronouns but also with possessive formants in nouns denoting the subject of possession. This is due to the fact the "words have grammatical category of the $3^{\text {rd }}$ person (there may be more than one in sentences) resulting in the deletion of the first term that causes confusion as it gets unclear possessiveness connection" (Avrorin 1959). The main role in the expression of the subject and numeral of possessiveness refers to personal possessive affixes, and not the first part of the structure. In order to properly understand the nature of the category of possessiveness as a morphological category, it is necessary above all to determine the nature of expressed value. Basically value of possessiveness is regarded in relations between objects, when one of them has a direct relations and impact on another, or it is an integral part.

At the core of the division of value elements which are either required or optional there must be a common feature, rather than a specific expression. Any element in word form is a concrete expression of a common feature. Thus, the "possessiveness" is a concrete realization of a common feature of "category".

However, if you put in the basis of classification not a common attribute (category) but its specific expression (possessiveness), the nouns are divided into two parts between which there is a close connection. The existence of a simple noun implies a very high probability of existence of noun possessives which differs from the first by the presence of the possessiveness affix. Thus, if the classification is based on a common feature some nouns may have a particular value of this feature as obligatory or optional. If it is taken as a basis for the classification of a specific characteristic value, it is always characterized by a series of nouns as a mandatory sign.

\section{Conclusion}

Thus, examining ways and the means of expression of the category of possessiveness the following circumstances should be taken into account: 1) what a given method presents; 2) how widely it is used in the target language; 3) what part of speech it expresses. 
To accept a possessive element (in this case an affix) as a grammatical unit, it is necessary to demonstrate that this is a mandatory affix. At first sight it may seem that possessive affixes are typical of any noun, however, this kind of formalization is not necessary. An element can be considered mandatory if presented in all word forms and are easy to be identified on any formal basis.

At the core of the division of elements into mandatory and optional there should be a common notion rather than its specific expression. Any element in word formation is a concrete expression of a common feature. Thus, the "possessiveness" is a concrete realization of a common feature "category".

However, if what is put in the basis of classification is not a common attribute (category) but its specific expression (possessiveness), the nouns are divided into two kinds between which there is a close connection. The existence of a simple noun implies a very high probability of the existence of the possessive form of a noun, which differs from the first case in having the affixes of possessiveness. Thus, if the classification is based on a common attribute, some nouns may have a particular value of this attribute as mandatory or optional. If a specific characteristic value is taken as a basis for classification, it always characterizes a series of nouns as mandatory.

\section{References}

Avrorin, V.A. (1959). Grammatika nanaiskogo jazyka [Grammar of Nanai language].Vol. 1. Phoneticheskoe vvedenie. Morphologija imennykh chastei rechi [Phonetic introduction. Morphology of substantive parts of speech]. Moskva, Leningrad: AN USSR Institut Jazykaznanija.

Barker, C. (1995). Possessive Descriptions.Stanford, CA.:CSLI Publications.

Chirkoeva, D.I. (2013). Categoriya prinadlezhnosti v jakutskom jazyke [The category of possessiveness in the Yakut language]. Yakutsk: NEFU Publishing House.

Dmitriev, N.K Akademianauk (1956). Issledovanija po sravnitelnoj grammatike t'urkskikh jazykov. Ch. 2. Morphologija [Studies on comparative grammar of Turkic languages. Part 2. Morphology]. Moskva: Izdatel'stvo AN SSSR.

Tenishev, E.R. (1988). Sravnitelno-istoricheskaja grammatika t'urkskikh jazykov. Morphologiya, 560.

Szabolcsi, A. (1994). The noun phrase. In F. Kiefer and K. E. Kiss (eds.), Syntax and semantics.Vol. 27. The syntactic structure of Hungarian, 179-274. San Diego: Academic Press.

Ubryatova, E.I. (1950). Issledovanija po sintaksisu jakutskogo jazyka. Prostoepredlozhenie [Studies on the syntax of the Yakut language. Simple sentence]. Moscow, Leningrad: Izdatel'stvo AN USSR.

Danilova, N. I. (1991). Mestoimenie v jakutskom jazyke [Pronouns in the Yakut language]. Yakutsk: Izdatel'stvo YANTS SO RAN.

Yastremsky, S.V. (1900). Grammatika jakutskogo jazyka [Grammar of the Yakut language]. Irkutsk.

Zimmer, K. (1971). Some general observations about nominal compounds. Working papers on language universals 5:1-21. Stanford University. 